\title{
Siri' na pacce: The Local Wisdom of Coastal Community Settlement Patterns and Its Existence amid COVID-19 Pandemic
}

\author{
Sri Aliah Ekawati*, Mukti Ali, Gafar Lakatupa, La Ode Muhammad Asfan, Stevanny Manga, \\ Fitha Rachma Sari
}

Department of Urban and Regional Planning, Faculty of Engineering, Hasanuddin University, Jalan Poros Malino, Km 6, Gowa, Sulawesi Selatan, Indonesia

Received September 3, 2021; Revised November 11, 2021; Accepted December 13, 2021

\section{Cite This Paper in the following Citation Styles}

(a): [1] Sri Aliah Ekawati, Mukti Ali, Gafar Lakatupa, La Ode Muhammad Asfan, Stevanny Manga, Fitha Rachma Sari, "Siri' na pacce: The Local Wisdom of Coastal Community Settlement Patterns and Its Existence amid COVID-19 Pandemic," Civil Engineering and Architecture, Vol. 10, No. 1, pp. 55 - 70, 2022. DOI: 10.13189/cea.2022.100105.

(b): Sri Aliah Ekawati, Mukti Ali, Gafar Lakatupa, La Ode Muhammad Asfan, Stevanny Manga, Fitha Rachma Sari (2022). Siri' na pacce: The Local Wisdom of Coastal Community Settlement Patterns and Its Existence amid COVID-19 Pandemic. Civil Engineering and Architecture, 10(1), 55 - 70. DOI: 10.13189/cea.2022.100105.

Copyright $\bigcirc 2022$ by authors, all rights reserved. Authors agree that this article remains permanently open access under the terms of the Creative Commons Attribution License 4.0 International License

\begin{abstract}
The handling of some issues due to the spread of the COVID-19 virus has been carried out in various cities, including the coastal city of Makassar. Efforts to break the chain of spread of the virus have been carried out starting from the recommendation to comply with health protocols to the establishment of regulations that limit people's daily movement. On the other hand, some local wisdom rooted in the lives of coastal residents also experienced a shift in meaning during this pandemic. This study aims to examine the meaning of local wisdom siri' na pacce in people's lives in coastal settlements, its manifestation in life during the COVID-19 pandemic and efforts that can be made as disaster mitigations. Methods of data collection were done by observation, interviews and questionnaires. The data collected was then analyzed by spatial analysis and description. This study found that the siri' value was influenced by bad stigma towards people with COVID-19 so that the meaning shifted in a negative direction. The value of pacce still has a positive form. It can be seen from community cooperation to help patients who are in self-isolation. At the end of the study, recommendations for pandemic disaster mitigation were formulated in coastal settlements, such as determining the location of temporary shelters and evacuation points.
\end{abstract}

Keywords Coastal Settlement, Local Wisdom, Siri' na pacce, Pandemic, COVID-19

\section{Introduction}

Various parts of the world are facing the COVID-19 pandemic. In order to break the chain of spread of the virus, the government issued health protocol rules such as wearing masks, maintaining distance, reducing and limiting mobility and even recommendations for activities at home. The first case of COVID-19 in Indonesia itself was found on March 23, 2020. The impact of the pandemic was also felt by coastal communities, especially fishermen, fish cultivators and salt farmers [1]. There was a significant economic downturn due to the general public's declining buying interest. The government's policy to close some areas also affects the distribution of fishery production for fishermen [2]. Makassar City is one of the cities in South Sulawesi Province, Indonesia that has not escaped the threat of the spread of the COVID-19 virus. As of January 2021, in South Sulawesi there were 37,765 cases of COVID-19 [3] and in Makassar City, there were 4.440 cases of COVID-19 [4].

The threat of pandemic COVID-19 can endanger assets 
located in coastal areas including residential areas. Moreover, in general, settlements located on the coast of Makassar City were classified as slum settlements with a linear, lined, irregular typology [5] and the buildings were made from woods so they were vulnerable to being hit by wind and waves. The high density in coastal settlements made it difficult for the community to apply health protocols, especially social and physical distance. The conditions of coastal settlements which were identical to slums accelerate the spread of disease.

Various studies have examined how local wisdom becomes a solution in social life that is in harmony with nature and how to deal with disasters. To face disasters, local wisdom was considered as a value that brings harmony between life and nature. Local wisdom is considered as good, wise and rooted values or ideas society [6]. According to Hos [7], local wisdom is the basis of community knowledge in responding to disasters by interacting with the ecosystem. However, it is very unfortunate that the current of modernization is so fast that it is able to shift the existence of local wisdom, it is even considered not adaptive a contrary to the progress of times.

Table 1. Previous Researches Related to Disaster Mitigation and Local Wisdom

\begin{tabular}{|c|c|c|c|}
\hline No. & Article Title & Conclusion & $\begin{array}{l}\text { Relation to disaster mitigation } \\
\text { (COVID-19) and local wisdom }\end{array}$ \\
\hline 1. & $\begin{array}{l}\text { Pengkajian Kerentanan Fisik } \\
\text { untuk Pengembangan Pesisir } \\
\text { Wilayah Kota Makassar } \\
\text { Tejakusuma, } 2011\end{array}$ & $\begin{array}{l}\text { Coastal areas in Makassar City are considered } \\
\text { vulnerable areas to disasters such as sea level rise, } \\
\text { erosion and other disasters. Specific planning is } \\
\text { required such as port planning, road infrastructure, } \\
\text { settlement and ecosystem. }\end{array}$ & $\begin{array}{l}\text { Relation to disaster mitigation: } \\
\text { physical mitigation for natural disaster } \\
\text { not pandemic. } \\
\text { Relation to local wisdom: none }\end{array}$ \\
\hline 2. & $\begin{array}{l}\text { Analisis Pengembangan } \\
\text { Kawasan Pesisir Berbasis } \\
\text { Mitigasi Sea Level Rise } \\
\text { (Kenaikan Muka Air Laut) } \\
\text { di Kawasan Kota Lama } \\
\text { Makassar } \\
\text { Hidayat, } 2012\end{array}$ & $\begin{array}{l}\text { The sea level on the coast of Makassar's Old City is } \\
\text { predicted to rise as high as } 122 \mathrm{~cm} \text { and will threaten } \\
\text { city assets such as the Port Area, offices, recreation and } \\
\text { settlements. The direction of mitigation is divided these } \\
\text { areas into two zones. Zone A is a vulnerable zone so no } \\
\text { new land cover is allowed. Zone B, the building } \\
\text { function is still allowed in accordance with the control } \\
\text { and direction of land use. }\end{array}$ & $\begin{array}{l}\text { Relation to disaster mitigation: } \\
\text { physical mitigation for natural disaster } \\
\text { not pandemic. } \\
\text { Relation to local wisdom: none }\end{array}$ \\
\hline 3. & $\begin{array}{l}\text { Penataan Karakteristik } \\
\text { Permukiman Kumuh Pesisir } \\
\text { untuk Pengelolaan Bencana } \\
\text { di Kota Makassar } \\
\text { Naing and Ikhsan, } 2015\end{array}$ & $\begin{array}{l}\text { In general, the characteristics of coastal settlements in } \\
\text { the study locations are as follows: medium to high } \\
\text { density, linear pattern following the road network, } \\
\text { narrow circulation lanes and lack of green open spaces. } \\
\text { Mitigation recommendation: to plan back the } \\
\text { roads/alleys in anticipation of the evacuation routes. }\end{array}$ & $\begin{array}{l}\text { Relation to disaster mitigation: } \\
\text { physical mitigation for natural disaster } \\
\text { not pandemic. } \\
\text { Relation to local wisdom: none }\end{array}$ \\
\hline 4. & 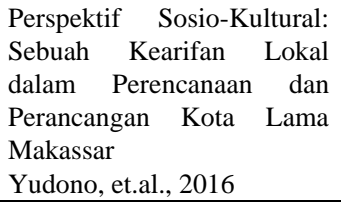 & $\begin{array}{l}\text { The influence of the Bugis-Makassar local wisdom } \\
\text { values is reflected in the arrangement of the coastal city } \\
\text { of Makassar. This can be seen from the arrangement of } \\
\text { public open spaces, the building mass and grid pattern } \\
\text { of road lines that facilitates access between houses and } \\
\text { social facilities in a settlement. }\end{array}$ & $\begin{array}{l}\text { Relation to disaster mitigation: none } \\
\text { Relation to local wisdom: local } \\
\text { wisdom values reflected in the } \\
\text { arrangement of city elements, not as a } \\
\text { solution to overcome the pandemic. }\end{array}$ \\
\hline 5. & $\begin{array}{l}\text { Kearifan Lokal dalam } \\
\text { Pembentukan Konfigurasi } \\
\text { Ruang Luar Permukiman } \\
\text { Tepi Laut Mariso } \\
\text { Syarif, E., } 2018\end{array}$ & $\begin{array}{l}\text { The influence of sipakatau (mutual respect) is reflected } \\
\text { in the pattern of individual settlements. On the other } \\
\text { hand, the influence of passarribattangngang (helping } \\
\text { each other) is reflected in clustered settlement pattern. }\end{array}$ & $\begin{array}{l}\text { Relation to disaster mitigation: none } \\
\text { Relation to local wisdom: local } \\
\text { wisdom values reflected in the } \\
\text { arrangement of city elements, not as a } \\
\text { solution to overcome the pandemic. }\end{array}$ \\
\hline 6. & $\begin{array}{l}\text { Eksplorasi Kearifan Budaya } \\
\text { Lokal sebagai Landasan } \\
\text { Perumusan } \quad \text { Tatanan } \\
\text { Perumahan dan Permukiman } \\
\text { Masyarakat Makassar } \\
\text { Beddu, et.al., } 2014\end{array}$ & $\begin{array}{l}\text { The values of local wisdom are reflected in the physical } \\
\text { arrangement of settlements in Makassar City. Siri' } \\
\text { (self-esteem): residential space patterns, road patterns, } \\
\text { building orientations and building shapes. Pacce } \\
\text { (solidarity): the layout and shape of the building. }\end{array}$ & $\begin{array}{l}\text { Relation to disaster mitigation: none } \\
\text { Relation to local wisdom: local } \\
\text { wisdom values reflected in the } \\
\text { arrangement of city elements, not as a } \\
\text { solution to overcome the pandemic. }\end{array}$ \\
\hline
\end{tabular}


Various studies related to disaster mitigation and local wisdom in coastal settlements have also been carried out. Tejakusuma [8] conducted a physical vulnerability study for the coastal development of the Makassar City area. Hidayat [9] has conducted research on the development of coastal areas based on mitigation of sea level rise in the Old City of Makassar. Naing and Ikhsan [5] also conducted a study on structuring slum settlements for disaster management in the coastal area of Makassar City. Regarding local wisdom, several studies have also been carried out. Yudono, et al. [10] examines the socio-cultural perspective that becomes local wisdom in the planning and design of Makassar City. Furthermore, Syarif [11] examines local wisdom in the configuration of the outer space of settlements on the shores of the Mariso Sea. Lastly, Beddu et. al. [12] explores local cultural wisdom as the basis for the formulation of housing and settlement arrangements for the Makassar community. It can be seen in Table 1, previous studies discussed the relationship between values and spatial areas without linking whether local wisdom could be a solution to issues or disasters that pose a threat. Therefore, this research seeks to explore local wisdom that exists in coastal settlements, how values shape urban spaces and whether local wisdom can be a solution to the COVID-19 pandemic that has lasted for the last two years in Indonesia since March 2020.

This study seeks to examine the implementation of local wisdom values of siri' and pacce in coastal communities' lives, especially during this pandemic. Siri' means the effort to maintain honor, dignity and self-respect wherever the person is. Siri' was also defined as a feeling of shame, abstinence from being weak, incapable and underestimated. Siri' was embodied in maintaining all behavior and appearance, coupled with efforts to develop potential [10]. The value of siri was defined as self-respect which includes the essence of human life, human relation with nature, human work, and human perception of time. The value of siri' placed humans above everything [12]. Meanwhile, pacce was defined as a sense of solidarity, the essence of human relationships $[10,12]$. Pacce was a person's compassion that encourages action and devotion in the name of love for God's fellow creatures. Thus, siri' napacce was interpreted as a community behaviour that is always awake as well as solidarity and togetherness [12].

This study was conducted to explore the challenges of implementing local wisdom, especially during the COVID-19 pandemic. This study was carried out by identifying tow forms of local wisdom of coastal communities, siri' and pacce, both in tangible and intangible forms. Furthermore, the characteristics of the settlements of the coastal area in the study location will be identified based on the local wisdom. Finally, it will be analyzed how the value of siri' na pacce can be a solution to overcome problems during the COVID-19 pandemic. The objectives of this research are as follows:

a) Identify the characteristic of coastal settlements in the tangible and intangible aspects of siri' na pacce;

b) Identify adaptation of new normal during the COVID-19 pandemic in coastal settlements;

c) Develop recommendation for local wisdom values in the face of the COVID-19 pandemic.

\section{Methods}

\subsection{Study Area}

This study took place in Tallo Village, Tallo District, Makassar City (Figure 1). In this location, there are several dense settlements located on the shoreline. This location was chosen because of the high density of buildings and population which creates vulnerability to disasters. In addition, coastal settlements are considered to still hold the values of local wisdom which are the foundation in everyday life.

\subsection{Data Collection}

Data collection was carried out by several methods based on the research objectives to be achieved. To obtain data related to tangible and intangible aspects, a literature review related to local wisdom in coastal settlements was carried out. Furthermore, to obtain data related to the characteristics of coastal settlements, field observations and documentation were carried out. Finally, the results of the analysis of the first and second objectives serve as material for compiling recommendation for structuring coastal settlements that are responsive to the COVID-19 pandemic based on local wisdom.

\subsection{Data Analysis}

The analysis used in this research is descriptive and spatial analysis. 


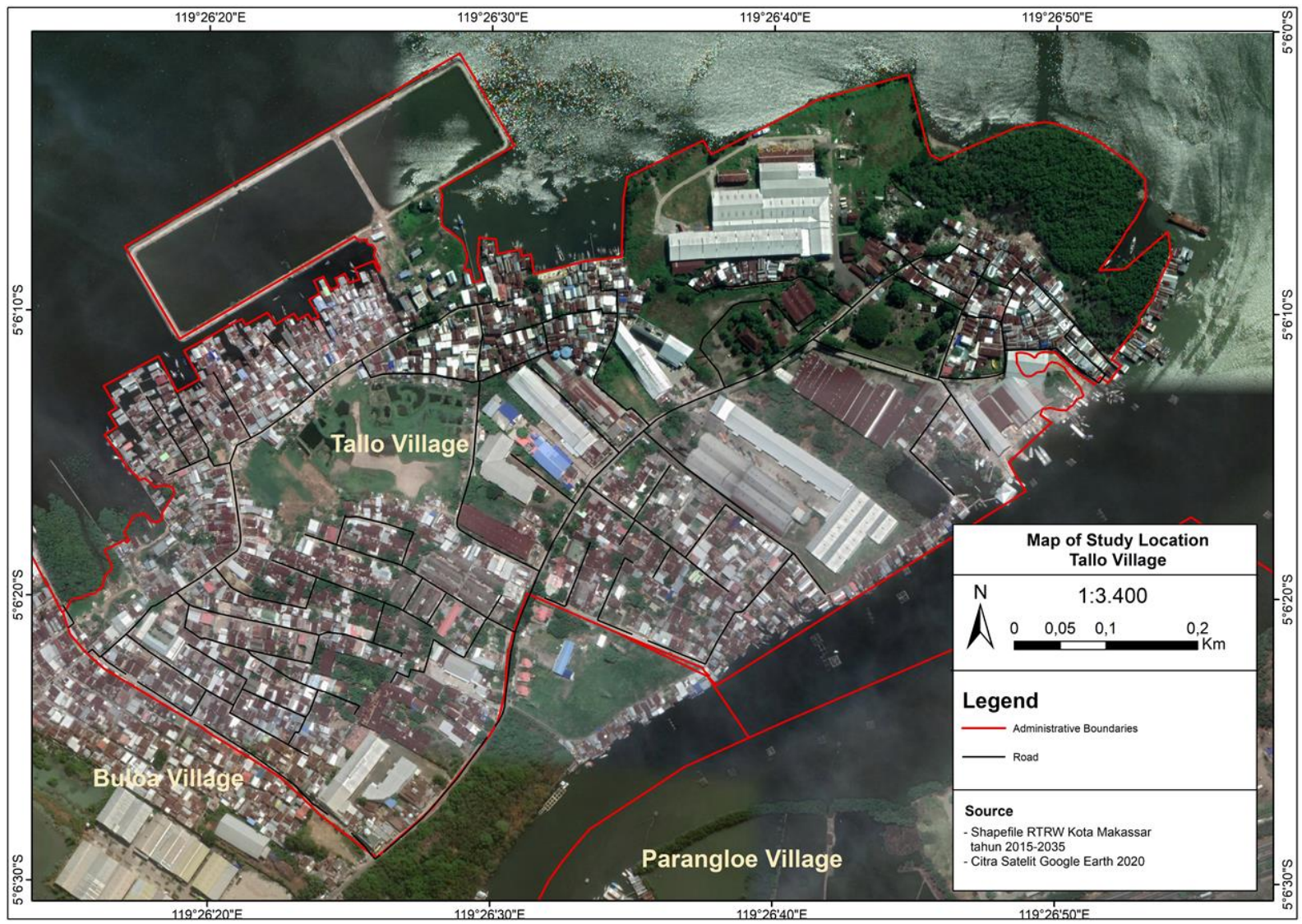

Figure 1. Study location in Tallo Village, Tallo District, Makassar City, South Sulawesi

\section{Findings and Discussion}

\subsection{Tangible and Intangible Aspects of the Local Wisdom of Coastal Community}

The manifestation of local wisdom in a society could be seen in the harmony between tangible and intangible aspects. Harmonization between human activities and the built environment was a manifestation of the application of values passed down from generation to generation. Built environment, such as residential area, was formed based on values, beliefs and customs that are firmly held by the community.

Research that examines the relationship between Bugis' local wisdom and urban spatial structure has not been widely carried out [10]. This section explored the values prevailing in the Bugis Makassar community and manifested in physical form. This sub-chapter described the relationship between intangible and tangible aspects. The literature search was carried out by studying the local wisdom of coastal communities, such as advice reflected in spatial form. The output of the findings in this chapter is physical manifestations of siri' and pacce values, which become variables to examine the following research questions: adaptation of new habits amid COVID-19 and recommendations for handling pandemics based on local wisdom.

\subsubsection{The Embodiment of Siri' Value in Residential Road Pattern}

Siri' value symbolizes self-respect and respect for others. In the life of the Bugis community, this value is reflected in the activities of friendship between the people. The Bugis community is also open and likes to communicate and interact with the surrounding environment. 

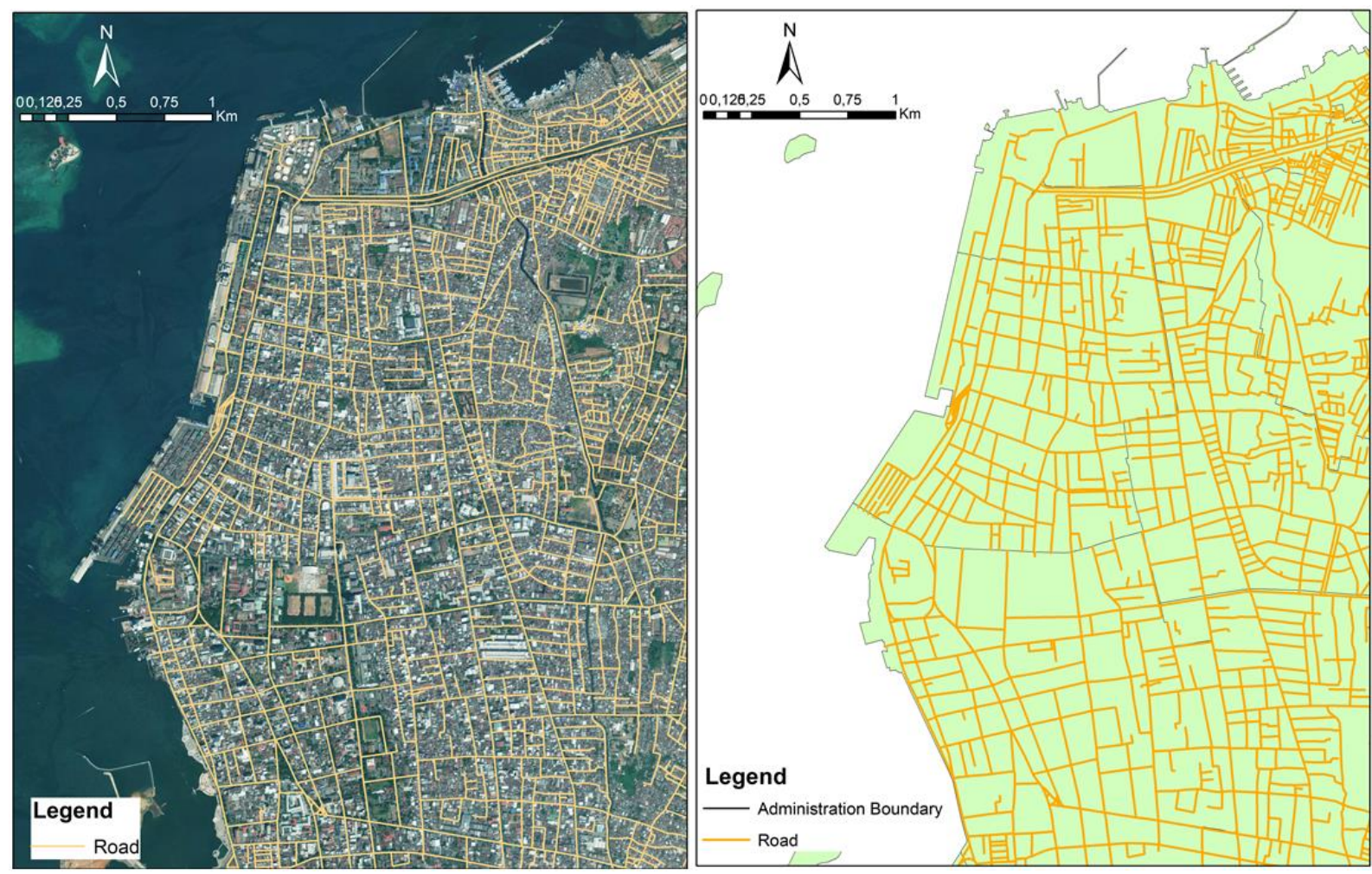

Figure 2. Map of Makassar City showing the grid pattern of roads [10].

The implications of this culture have an influence on the need for easy access to interact with. Communication, such as greetings, can occur on the road. The road pattern with a grid form is a formation in accordance with the siri' value $[10,15]$. The grid pattern is relevant to the ease of access, is open from all sides and very efficient to move in all directions. Figure 2 shows the road pattern in Makassar City. With a grid form, people can easily access all sides of the urban area. A road can be a symbol of self-esteem if it fulfills the community's interests [16].

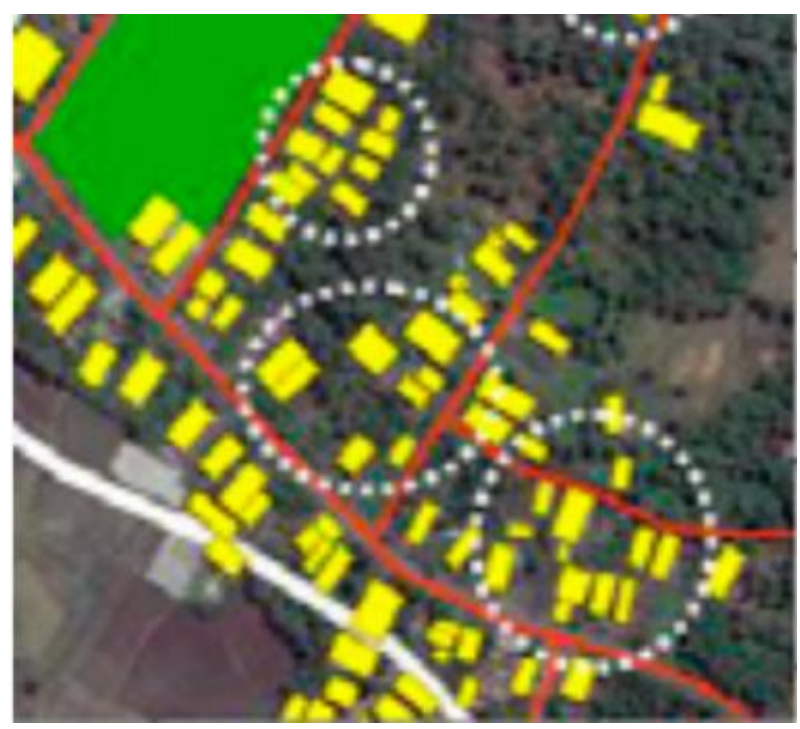

Figure 3. Bugise Village image map showing cluster pattern based on kinship [15]

\subsubsection{The Embodiment of the Pacce Value in the} Settlement Pattern

The value of pacce means kinship and solidarity. This value can be seen from the tendency of people to live close to their relatives. The value of pacce was reflected in the layout of the dwelling which tends to be grouped based on kinship, parents and emotional relationships (Figure 3).

Table 2. Tangible and Intangible Aspects in Local Wisdom of Coastal Settlement in Makassar City

\begin{tabular}{|c|c|c|c|}
\hline \multirow{2}{*}{ No. } & \multicolumn{2}{|c|}{ Intangible } & \multirow{2}{*}{ Tangible } \\
\cline { 2 - 3 } & Value & Meaning & Accessibility: grid pattern \\
1. & Siri & $\begin{array}{c}\text { Shame, honor, } \\
\text { dignity }\end{array}$ & $\begin{array}{c}\text { of roads, connected roads } \\
\text { to each other. }\end{array}$ \\
\hline 2. & Pacce & $\begin{array}{c}\text { Kinship, } \\
\text { solidarity }\end{array}$ & $\begin{array}{c}\text { Settlement pattern: } \\
\text { dwelling layout grouped } \\
\text { based on kinship. }\end{array}$ \\
\hline
\end{tabular}

Based on the relevant previous studies related to local wisdom, it could be understood that the tangible aspect greatly influences the intangible aspects. Values such as siri' na pacce, formed the basis for the information of community settlement patterns (Table 2). Ease of access and grouping of building masses were symbols of local wisdom in coastal settlements. Mutual respect was manifested by easy access. The grid-shape road pattern was the right choice for ease of access since it was connected to one other. The settlement pattern supported solidarity and kinship: clustered based on kinship. Every member of society always wanted to stay close to people close to them, 
either by blood or emotionally close.

\subsection{New Normal Adaptation amid COVID-19}

During the COVID-19 pandemic, gathering activities, especially in public spaces, are limited. This is done to break the chain of the spread of the COVID-19 virus. The advice to keep the distance and stay at home are some examples of rules applied during the pandemic. A healthy living culture, such as diligently washing hands, maintaining environmental cleanliness, and eating food with balanced nutrition, is also a must, especially during a pandemic.

This study seeks to adapt new habits based on health protocols [13] from the perspective of intangible aspects extracted from the values of local wisdom siri' na pacce.

\subsubsection{Accessibility}

The spatial form of these two values can be seen from the ease of access, especially the grid-shaped road pattern. The pattern of interconnected roads facilitates accessibility which is a requirement in mitigating the COVID-19 pandemic disaster. The methods to measure spatial accessibility mainly include the nearest distance method. The grid road pattern is considered to have high accessibility so that it becomes an evacuation route that makes it easier for vehicles, especially ambulances, to go to a referral hospital during an emergency.

However, the problem of settlement density may be an obstacle to ease of accessibility. At several points in Tallo Village, it is classified as a settlement that has a moderate concentration of density with a distance of less than two meters from houses. This is one of the inhibiting factors for the process of evacuating COVID-19 patients in several narrow alleys, but the road structure in the form of a grid can provide several alternative options for easy access to several points on a narrow road.

\subsubsection{Settlement Pattern}

The value of pacce is manifested in the spatial pattern of settlements which are grouped based on kinship. This is an advantage because, based on health protocols, moral support from family and relatives is needed to maintain people's mental health during the pandemic. However, the health protocol recommends that someone who is forced to serve his family in self-isolation must maintain a distance, wear a mask and maintain cleanliness. Those who are infected are prohibited from doing activities outside their house and making physical contact with other people. The health protocol also recommended separating activities between healthy family members and those in self-isolation, such as: washing dishes, toileting and garbage. Another thing that also needs to be considered is the density of buildings in one area and the density of residents in one building.

\subsection{Findings: Characteristics of Coastal Settlements and Communities}

\subsubsection{Tangible Aspects in Coastal Settlement Culture}

Siri' values are seen as shame that involves self-esteem. However, during the COVID-19 pandemic, the community situation tends to be negative. Based on the results of interviews, there is a sense of shame for residents who live in coastal settlements to admit that someone has been infected with the COVID-19 virus. The negative stigma of people with this disease makes people silent and embarrassed to report their condition. This can endanger the surrounding environment if infected residents do not isolate themselves and do not immediately receive further medical treatment.

On the other hand, the pacce value has a positive impact on coastal communities. The value of pacce is compassion for someone who encourages that act of helping. Still based on the results of interviews, residents do not hesitate to provide assistance to their neighbors who are self-isolating. The forms of assistance among residents include: providing food, basic necessities, and medicines and vitamins.

\section{A. Accessibility}

The road pattern in Tallo Village has formed a grid and is interconnected. However, the grid formed is not perfect (Figure 4). The road network that is interconnected with each other increases accessibility in Tallo Village greatly facilitates the movement of people, especially COVID-19 patients, to be taken to the nearest referral hospital. 


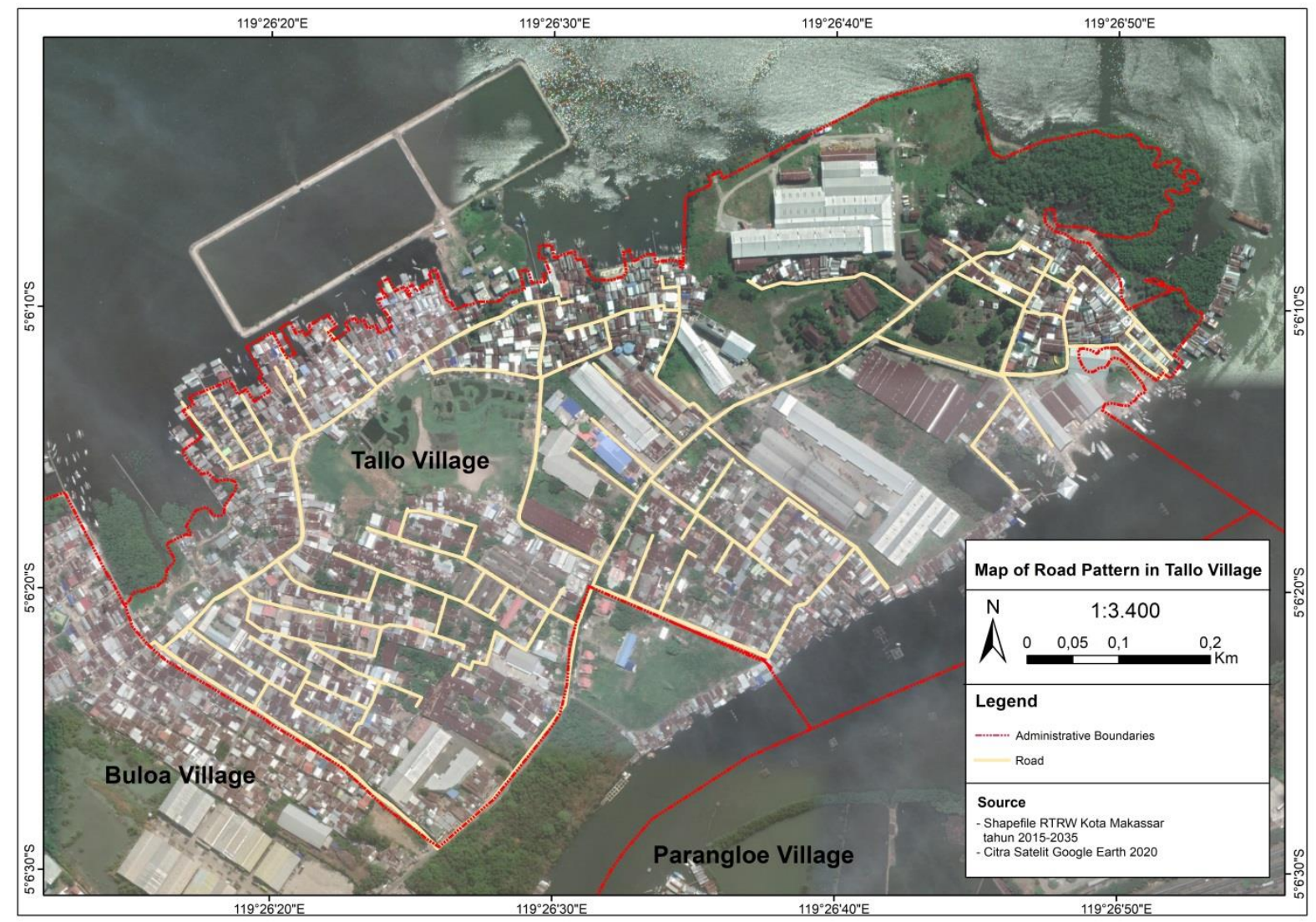

Figure 4. Road Pattern in Tallo Village Forms an Irregular Grid

There are four types of roads in Tallo Village based on their width (Figure 4 and 5). First, the road with a width is five meters. This road is an arterial road with asphalt material. The second type of road has a width of four meters with asphalt material. These two types of roads are considered sufficient, at least, the road width was able for the movement of four-wheeled vehicles, including ambulances and its accordance with the COVID-19 pandemic disaster mitigation standards. In addition, according to Government Regulations, which is Peraturan Pemerintah No.34 Tahun 2006, a road with a width of five meters is recommended for a vehicle with 3 wheels or more.
The road with a width least of all 3.5 meters, it intended, so the road width was passable during emergencies.

Furthermore, the types of roads that do not meet the minimum width standards for mitigation are roads with two and one meter. This type of street dominates Tallo Village. The road with a width of two meters has paving block material. Meanwhile, the one-meter-wide road is only wide road is only made of wood. In general, roads made of wood are footbridges between houses located above a body of sea water. The size and material of these roads make it more difficult to move four-wheeled vehicles and ambulances 


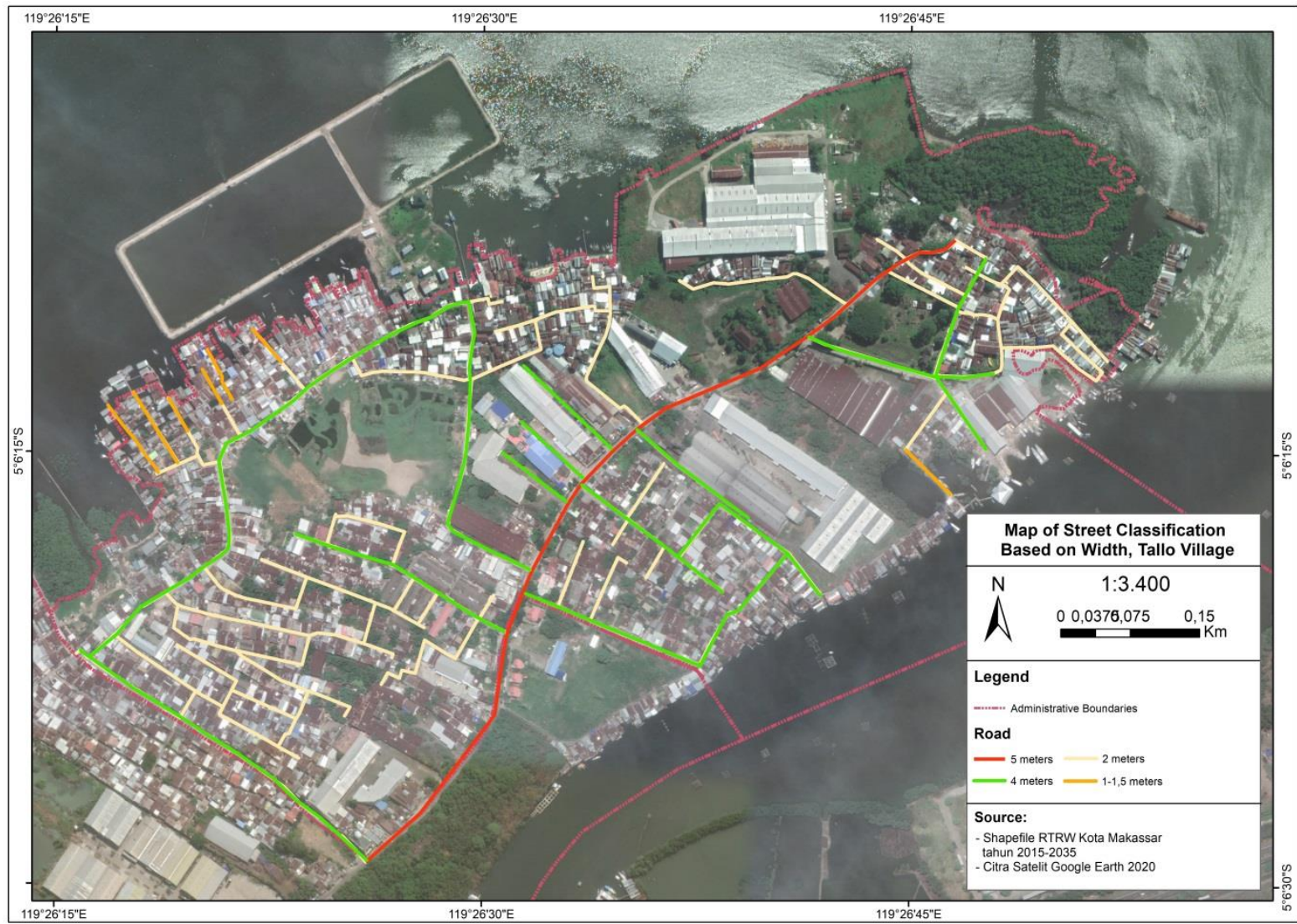

Figure 5. Street Classification Map Based on Width in Tallo Village
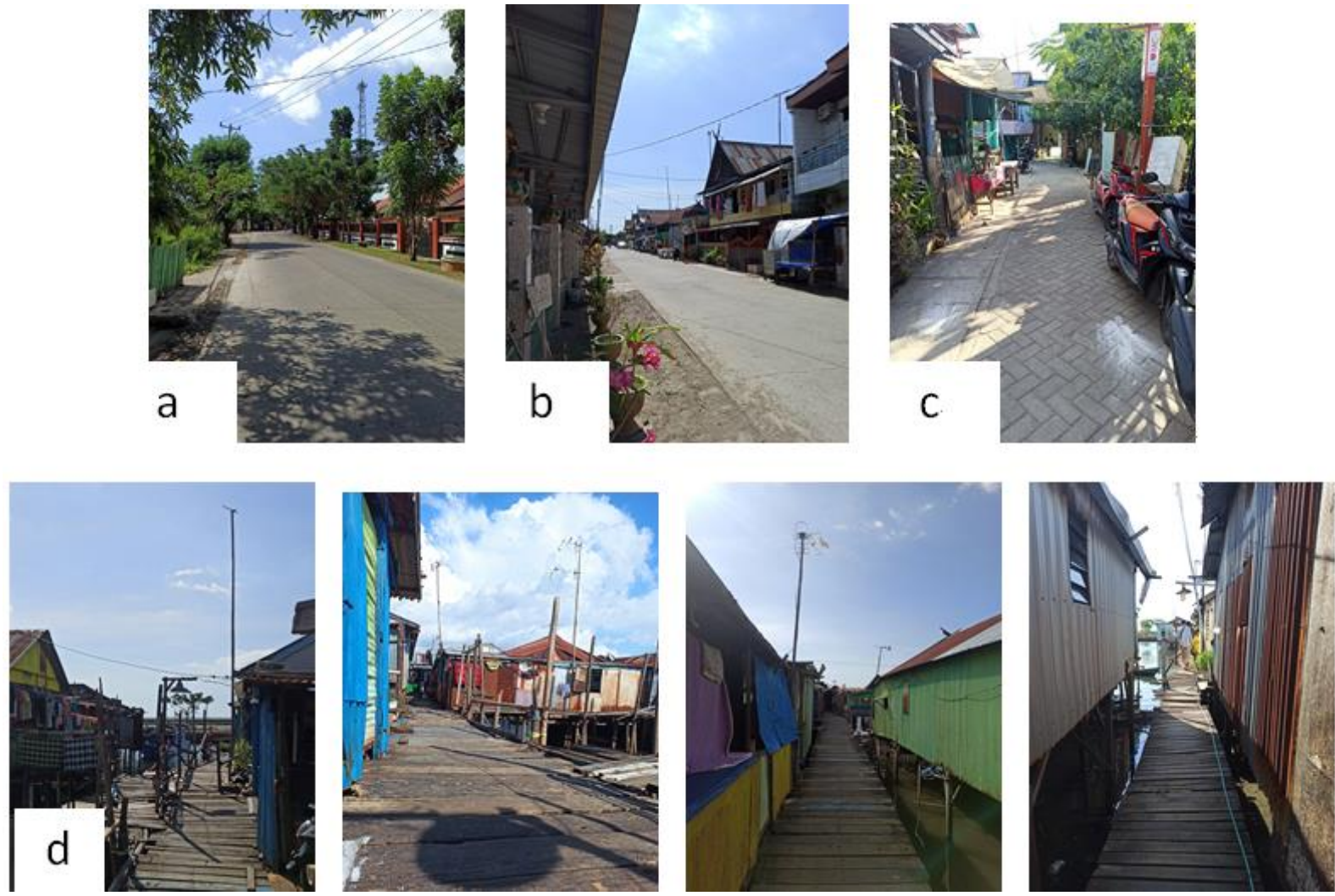

Figure 6. The Road Situatuin in Tallo Village: 5 meters (a); 4 meters (b); 2 meters (c); and 1-1,5 meters (d) 


\section{B. Settlement Pattern}

Based on the questionnaire results, it was identified that $44 \%$ of respondents answered that they had a kinship with their neighbors. In general, residents in Tallo Village live close to their parents, siblings, and nephews. As for residents who are not related by blood, they still have close relations as neighbors.

Living close to family members, especially parents and siblings, can have a positive impact on someone. Moral support and intense interaction can provide a sense of calm and relieve stress for the community. This is especially important during the COVID-19 pandemic. Mental health also needs to be maintained because it greatly affects a person's physical health. Being close to relatives is considered to be one on the supporters to maintain mental health.

This distance between buildings in Tallo Village, especially settlements on water, is too close. Based on the field survey results, the buildings in the study location are 1-1,5 meters apart (Figures 7-a and b). The house located in the alley has no distance at all from the house on the left and right (Figure 7-c). This condition can increase the risk of spreading the COVID-19 virus. Coupled with a house with a small area, fragile materials and narrow circulation paths around the house; it is difficult for people to keep their distance from each other. The gap between houses that are less than two meters forms a space that can become a nest of disease because it is used as a place to store used goods or trash cans.
The next characteristic of coastal settlements is related to the density of the area. One way to know the density of the area is to calculate the Building Covered Ratio (BCR). Based on the implementing regulation of the Republic of Indonesia government about building codes, it is known that the density level of a location can be identified from the Building Covered Ratio (BCR) classification (Table 3). Table 3 shows that the BCR percentage for the settlements is $40 \%-60 \%$ of the total area. The remaining space is used for open spaces, especially green spaces.

Tabel 3. Location Density Classification based on BCR

\begin{tabular}{|c|c|c|}
\hline Classification & Location & BCR (\%) \\
\hline High density & Commercial area, city center & $>60 \%$ \\
\hline $\begin{array}{c}\text { Medium } \\
\text { density }\end{array}$ & Settlement & $40 \%-60 \%$ \\
\hline Low density & $\begin{array}{c}\text { Suburbs/outside the city, water } \\
\text { catchment areas }\end{array}$ & $<40 \%$ \\
\hline
\end{tabular}

Based on the interpretation of images maps, it is known that the study has an area of 50 hectares. The percentage of $\mathrm{BCR}$ can be calculated by the formula below:

$\begin{aligned} \mathrm{BCR} & =\frac{\text { Total area of building base }}{\text { Area }} 100 \% \\ \mathrm{BCR} & =\frac{16.66 \times 100 \%}{50} \\ & =33.32 \%\end{aligned}$
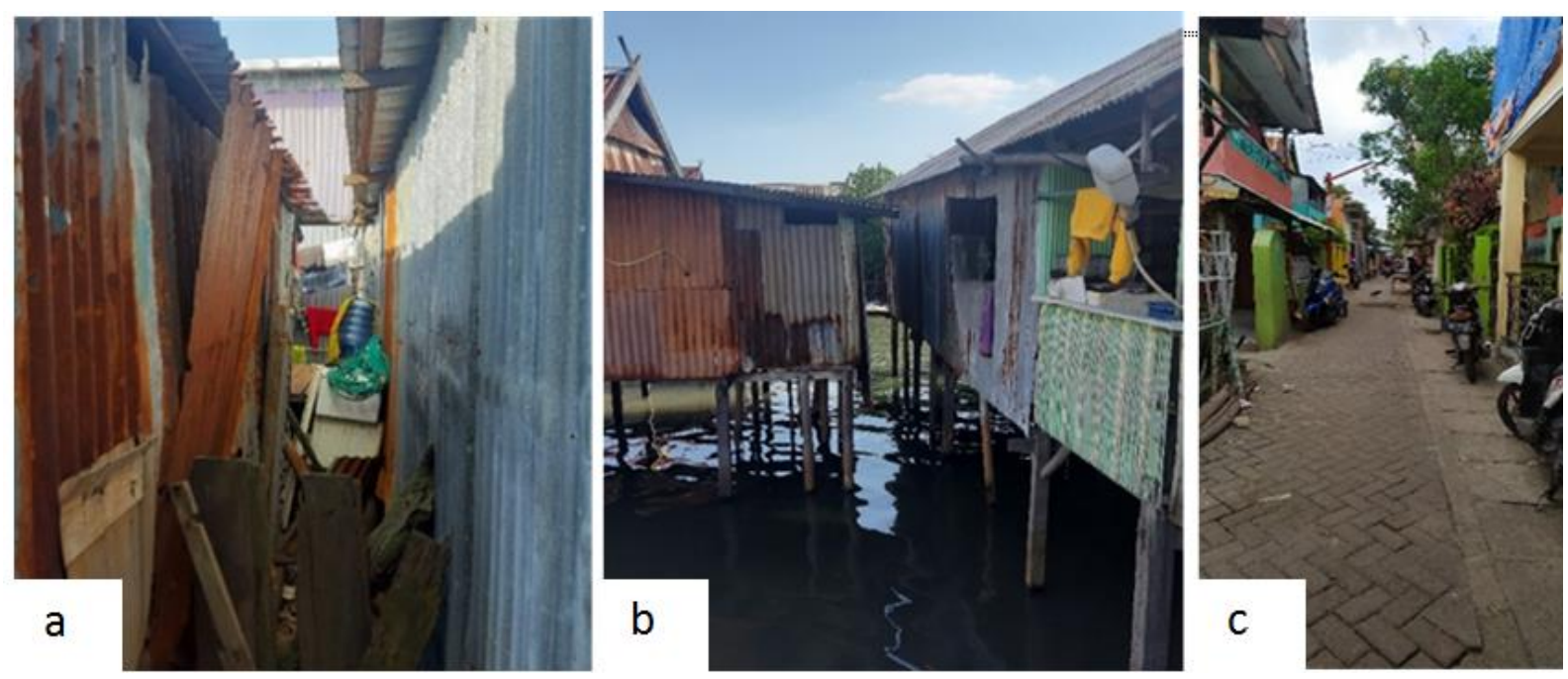

Figure 7. The Distance between Houses in The Study Location is Less than Two Meters 


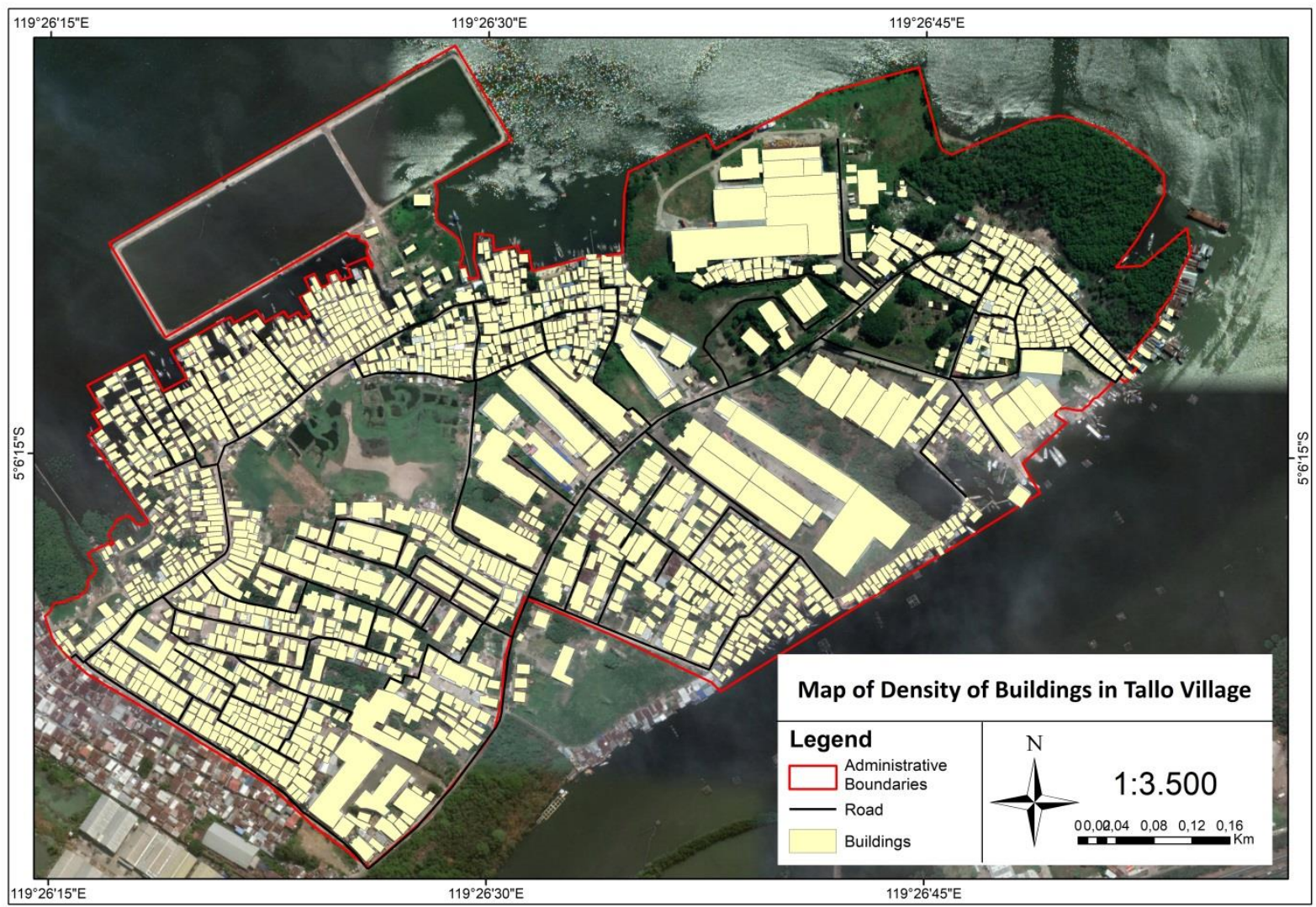

Figure 8. Map of Density of Buildings in Tallo Village

Based on the calculation results, it is known that the BCR of Tallo Village is 33\%. This percentage indicates that Tallo Village classified as low-density location. However, based on the spatial analysis, the concentration of building density lays on the coast, especially in the west and south of the study area (Figure 8). Meanwhile, to the north, the study area was dominated by large building with warehousing functions. The Tallo Kings Tom Complex has about $25 \%$ of the total green open space (Figure 8-east side).

Even though it is classified as medium density, Tallo Village is still considered vulnerable to the spread of the COVID-19 virus. The concentration of the density of houses less than two meters away is one of the factors that can cause rapid transmission. In addition, people's houses on the coast are built on water (Figure 6-d and Figure 7-b) making the sanitation system, such as the availability of trash cans, bathrooms and clean water, very limited. Hygiene issues are one of the regional issues that can increase the risk of spreading the COVID-19 virus. The hygiene issue in the Tallo Village is one illustration of the problems that commonly occur in dense settlements in Indonesia and can trigger the spread of COVID-19. Urban area density, low hand washing habits, low access to clean water and limited personal protective equipment are some of the causes of the COVID-19 virus being transmitted indirectly [14].

\subsection{Rethinking the Local Wisdom and Disaster Mitigation amid COVID-19 Pandemic}

Based on the description of the results of the analysis of the characteristics of coastal settlement areas, several things can be identified related to the tangible and intangible aspects of local wisdom during the COVID-19 pandemic.

a) The negative stigma of society towards people who have COVID-19 makes them very closed and tends to keep their condition a secret;

b) A sense of brotherhood helping each other in meeting the daily needs of residents who are in self-isolation;

c) The pattern of settlements formed based on family relationships is an aspect that supports the psychology of residents, especially those with COVID-19;

d) High building density and lack of adequate sanitation facilities can accelerate the spread of the COVID-19 virus;

e) Kinship affects the distance between houses and the size of the road. It causes there are some narrow alleys are constraint ambulance to evacuate patients.

These various aspects are the basis for rethinking the values of local wisdom siri' na pacce in a spatial context during the COVID-19 pandemic. The following is an 
explanation of solutions that can be used to mitigate the COVID-19 pandemic disaster.

\subsubsection{Educate the Public Regarding the COVID-19 Pandemic}

Negative stigma against COVID-19 can be changed by educating the public. Exposure from an expert is needed so that the public understands the impact if someone closes themselves when infected with the COVID-19 virus. Shame on siri' for the community if they experience failure or suffer from a disease, should be put aside first. With an understanding of COVID-19, it is hoped that the community will be more cooperative if they feel the symptoms so that the chain of spreading the virus can be immediately broken.

\subsubsection{Temporary Shelter in a Coastal Residential Area}

The density of buildings in coastal settlements in Tallo Village can accelerate the spread of the COVID-19 virus. In addition, the number of families living in one house is categorized in high level; there are about five to eight people who live in one house. With a limited house area, 45 to $50 \mathrm{~m}^{2}$, the spread of the virus will be difficult to avoid and self-isolation will not be facilitated in the house. Therefore, a solution is needed so that residents affected by the virus with asymptomatic and mid symptoms can undergo isolation quietly without threatening other family members.

The construction of temporary shelters is a possible solution. Temporary shelters are placed in coastal residential areas according to the Ministry of Social Affairs standards. The feeling of security and comfort because they still feel close to relatives can maintain patients' mental health, which also affects their physical health. The determination of temporary shelters is carried out by referring to the Guidelines for Preparing Shelter Facilities for Quarantine and Isolation related to Community-Based COVID-19 from the Ministry of Social Affairs [13]. The criteria for the shelter include: a) Prioritizing public facilities and social facilities, such as hajj dormitories, village halls, government buildings, emergency tents and so on;

b) Not in a densely populated area;

c) There is a distance of more than two meters from a house or other building;

d) There is access to four-wheeled vehicles and evacuation access to COVID-19 referral health services;

e) Buildings and locations are safe from other hazards such as floods, landslides and tsunamis.

Based on the regulations and the determining factors for the COVID-19 temporary shelter, the assumptions used in determining the location of the shelter are as follows:

a) Temporary shelters use public facilities or emergency tents with a size of $6 \times 14 \mathrm{~m}$, so that one shelter can accommodate 21 patients;

b) There is space between buildings or tents of at least 2 $\mathrm{m}$;

c) Shelters are expected to be able to accommodate the space requirement per person, which is $4 \mathrm{~m}^{2}$;

d) Shelters have open spaces capable of enforcing health protocols, especially keeping a minimum distance of $2 \mathrm{~m}$;

e) The location is not prone to disasters, especially coastal disasters so that it is at least $100 \mathrm{~m}$ from the beach boarder;

f) Radius 10-15 $\mathrm{m}$ from the road network with a width of $4 \mathrm{~m}$;

g) Easy to reach from settlements, so that the distance between the shelter and the center of the settlement is not more than $200 \mathrm{~m}$.

Based on several assumptions about temporary shelter, one potential location is expected to consist of two emergency tents, an open space, and two lavatories. The total area required is at least $450 \mathrm{~m}^{2}$ which can facilitate 42 COVID-19 patients. As for the illustration of the COVID-19 temporary shelter using emergency tents, it can be seen in Figure 9. 

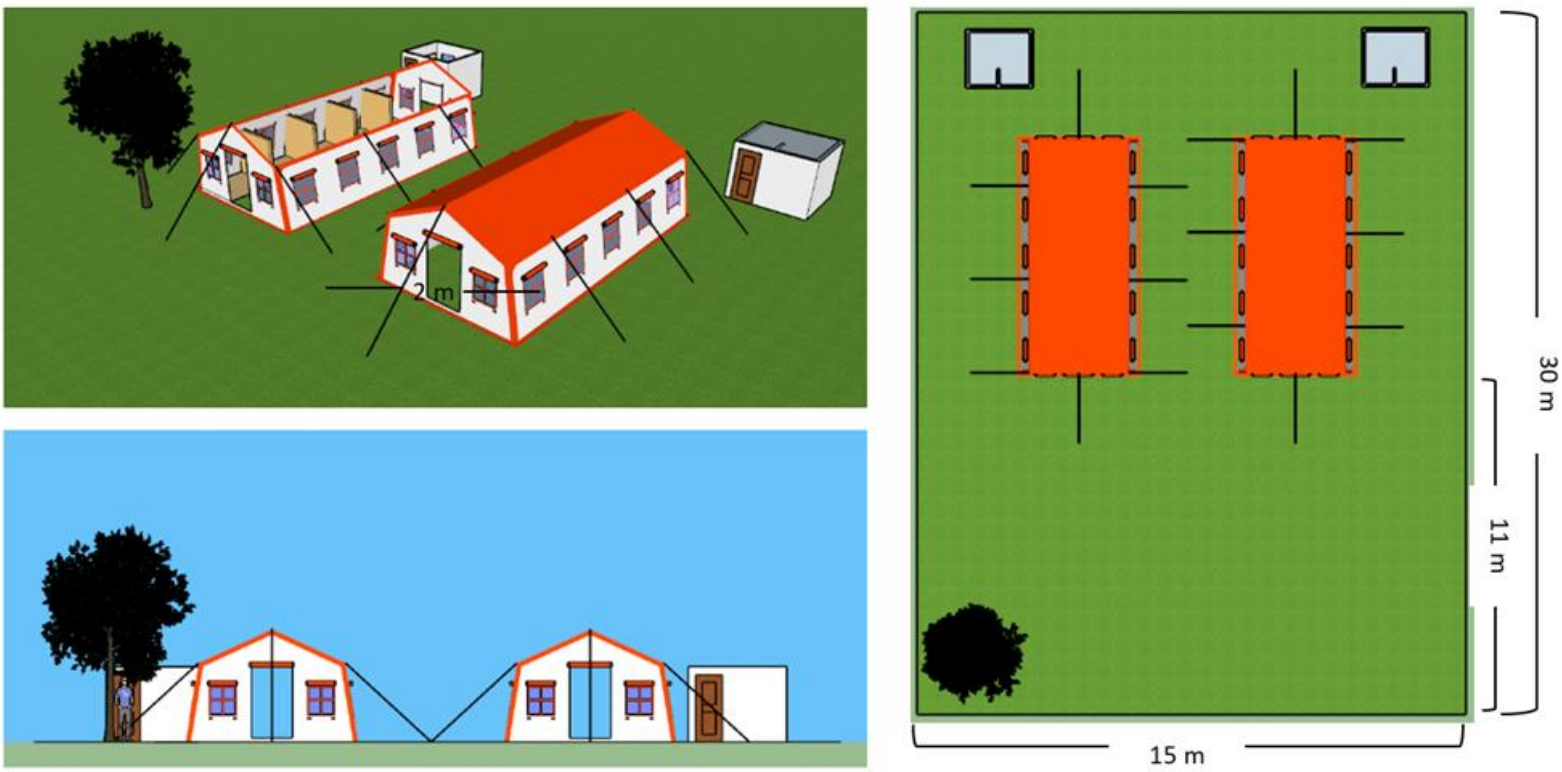

Figure 9. Illustration of the Need for Emergency Tent-Based COVID-19 Temporary Shelters

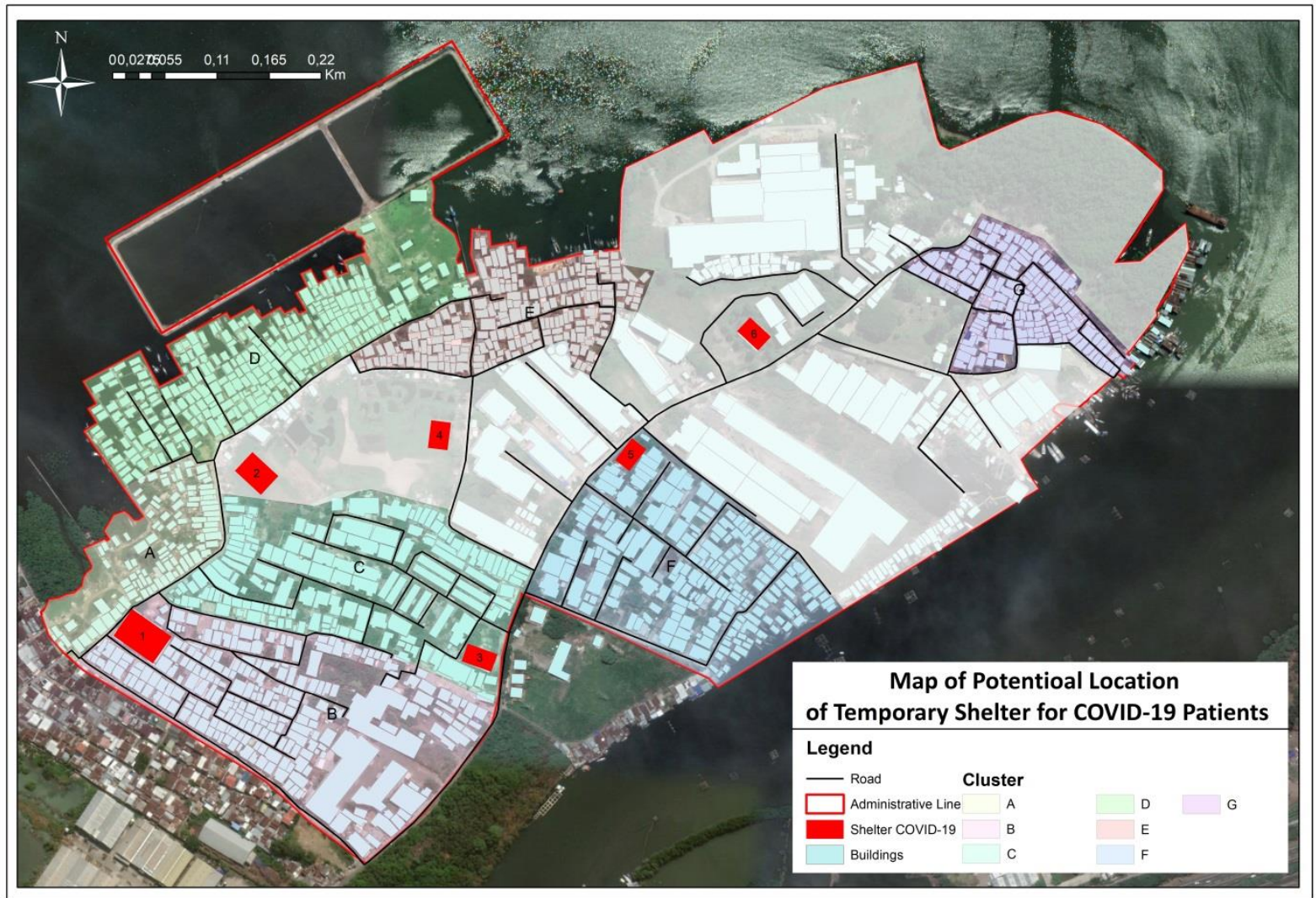

Figure 10. Map of Potentioal Location of Temporary Shelter for COVID-19 Patients

Based on these criteria, the direction of the location of the COVID-19 shelter in Tallo District was analyzed spatially. The results of the analysis found several potential points consisting of three existing buildings and three vacant open spaces. The existing buildings are two schools and one hall. Meanwhile, the three open spaces are green space located outside the residential cluster. The recommendation of the COVID-19 temporary shelter location can be seen in Figure 10.

Based on the results of the analysis, there are six potential locations for the recommendation of the COVID-19 temporary shelters in Tallo Village (Table 3). 
Table 4. Potential Location of Temporary Shelter

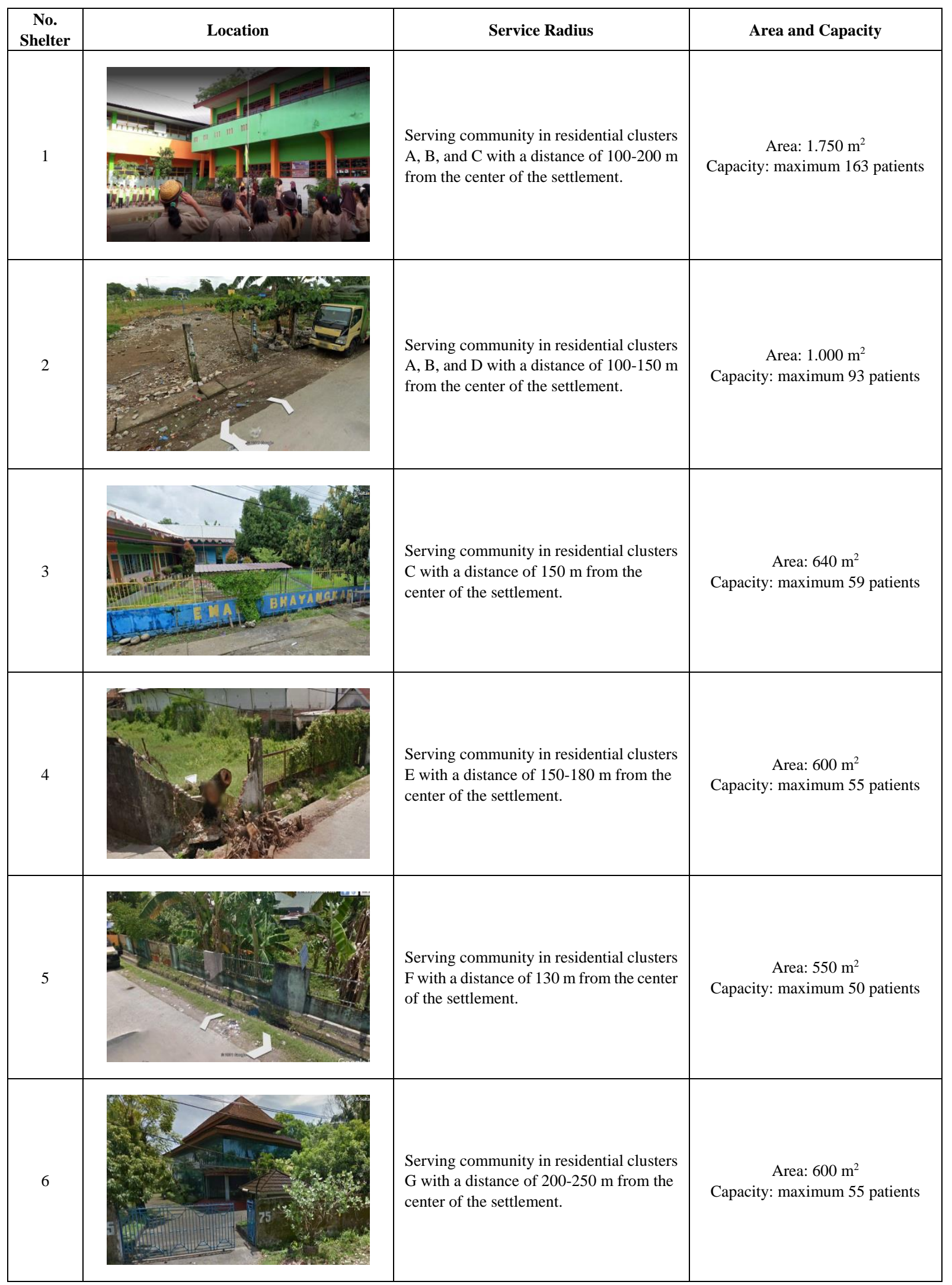




\subsubsection{Evacuation Routes in Dense Coastal Settlements}

The pattern of interconnected roads facilitates accessibility which is a requirement in mitigating the COVID-19 pandemic disaster. The grid road pattern is considered to have high accessibility so that it becomes an evacuation route that makes it easier for vehicles, especially ambulances, to go to a referral hospital during an emergency. A grid-shaped road pattern has been applied to the study site based on the existing conditions, although it is not fully connected. With the road pattern in the form of a grid, Tallo Village is classified as having a high level of accessibility. This is needed to increase the effectiveness of handling COVID-19.

In an emergency situation, the COVID-19 referral hospital will deploy a medical team to immediately evacuate patients who are declared positive for COVID-19. The procedure for picking up COVID-19 patients is regulated on the Service Operational Standard organized by the COVID-19 Task Force together with the referral hospital.
Although the grid pattern, the road width ranges from 1.5-5 meters. Those roads cannot be passed by ambulance and other four-wheeled vehicles.

Determination of evacuation points of evacuation routes with the fastest route needs to be done. The results of the spatial analysis identified as many as nine evacuation points. Aspects to be considered include: easy to access, marked with a minimum road width of 4 meters, safe from other hazards, and easy to recognize and reach by the local community. The evacuation points are located at a location with a minimum road width of $4 \mathrm{~m}$, so it is easily accessible by ambulance. In addition, the evacuation points are located more than $50 \mathrm{~m}$ from the coastline, so it is safe from other hazards such as tsunamis. The evacuation points are easily recognized by the surrounding community because they are located at the entry-exit access points to their residential area. The determination of the evacuation points also considers the evacuation route that connects from the evacuation points to the COVID-19 referral hospitals (Figure 11).

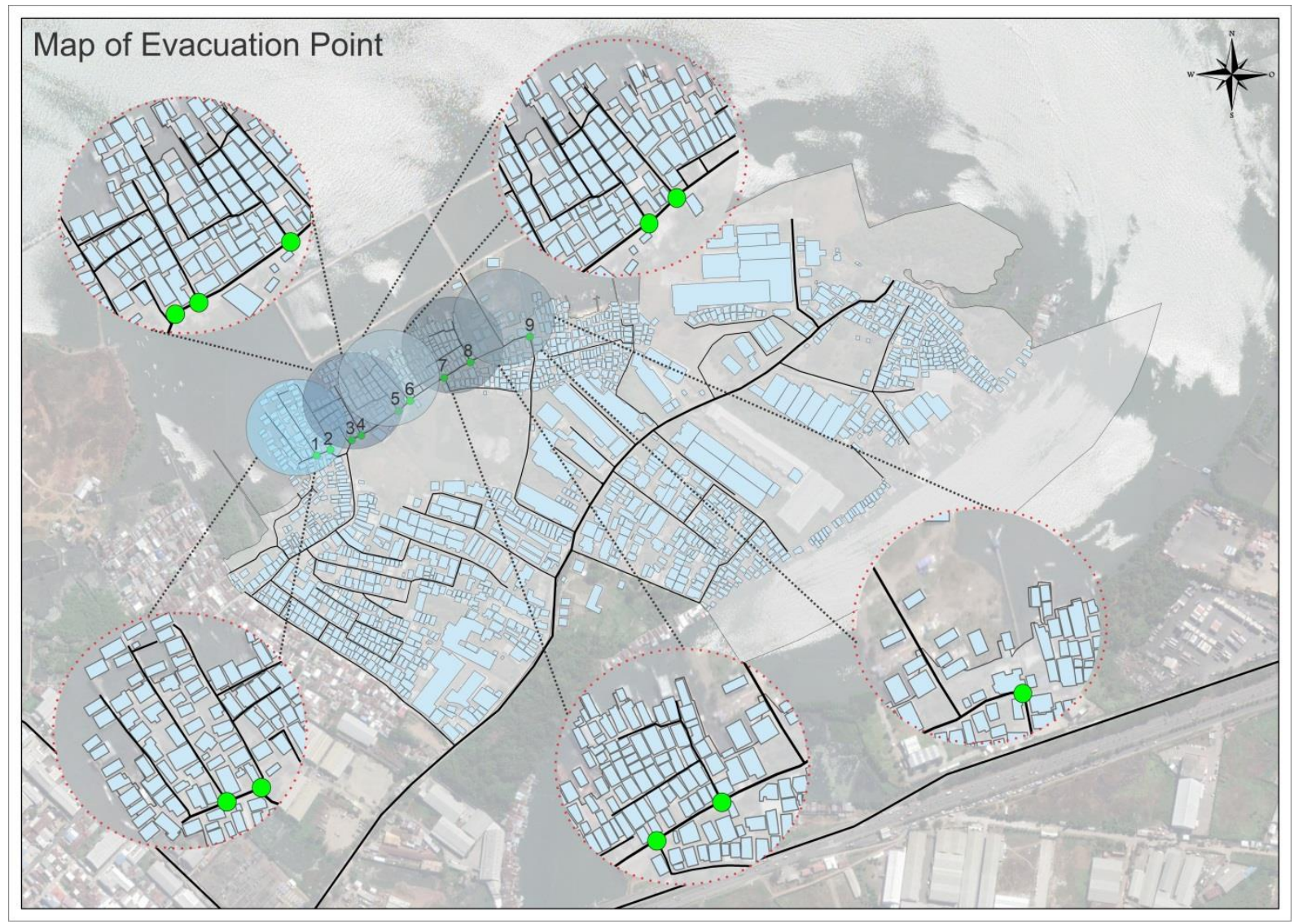

Figure 11. Map Showing Evacuation Points in the Coastal Settlements of Tallo Village 
Map of the Location Of the

CoVID-19 Referral Hospital from Study Location

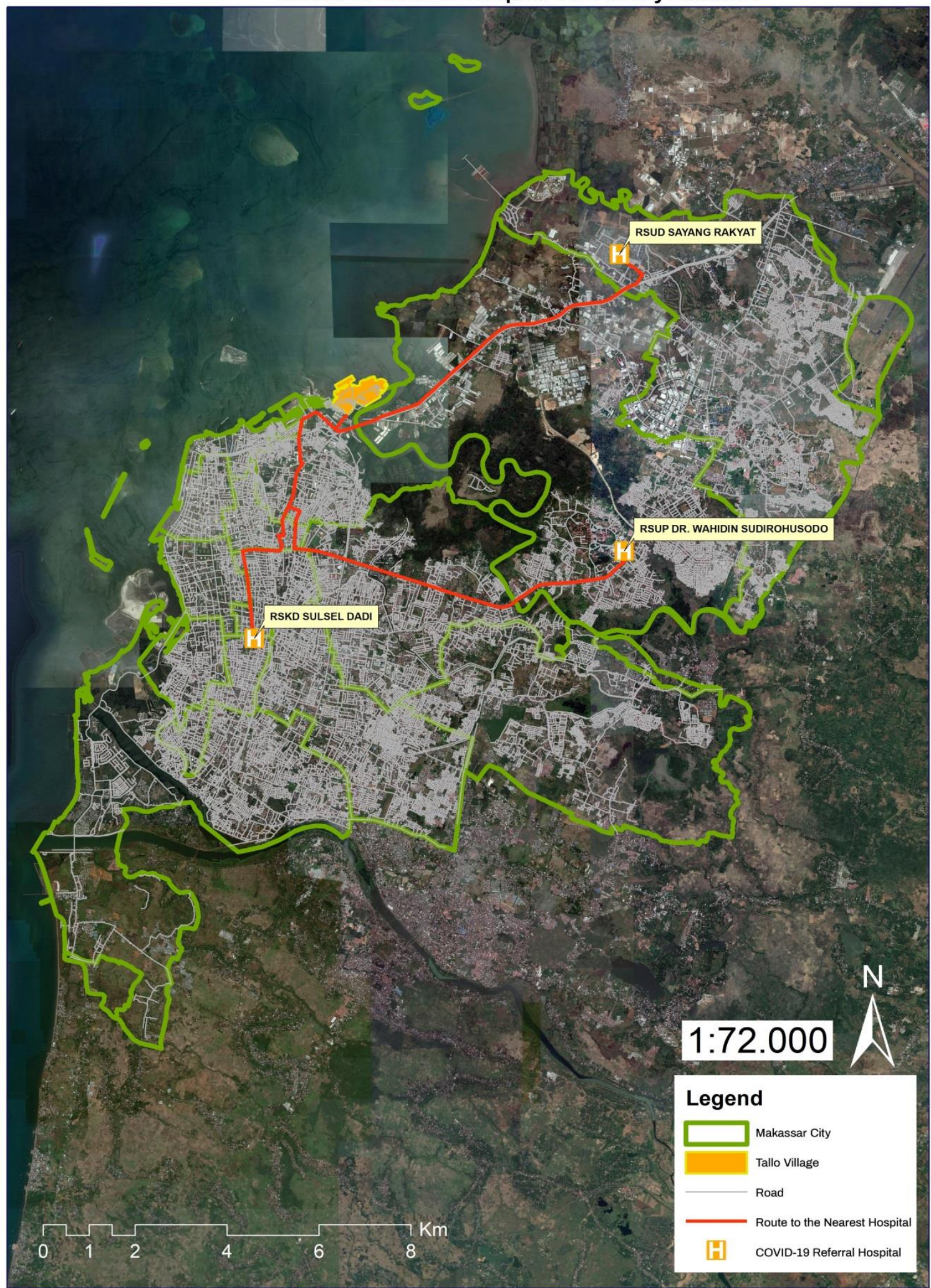

Figure 12. Map of the Location of the COVID-19 Referral Hospitals from Study Location 


\section{Conclusions}

The existence of local wisdom values siri' na pacce influences people's lives in the coastal settlements of Tallo Village, Makassar City. The siri' value that symbolizes high self-esteem actually makes people choose to remain silent if they are infected with the COVID-19 virus. However, the value of pacce which is interpreted as a brotherhood is seen in the cooperation of the residents in meeting the needs of those who are self-isolating. From the spatial aspect, the determination of temporary shelter points and evacuation routes can help residents and medical personnel deal with COVID-19 patients without threatening the safety of family members and increasing the burden on hospitals.

\section{Acknowledgements}

This research was fully funded by Lembaga Penelitian dan Pengabdian Masyarakat Universitas Hasanuddin in 2021.

\section{REFERENCES}

[1] Amabari, M, "Catatan Akhir Tahun: Perjuangan Masyarakat Pesisir Keluar dari Tekanan Pandemi COVID-19", MONGABAY Situs Berita Lingkungan, www.mongabay.co.id (accessed Jan. 12 ${ }^{\text {th }}$ 2021).

[2] Ratri, A.M, "Pandemi COVID-19 dan Nelayan: Menyoal Dampak pada Keberlanjutan Penghidupan", Jurnal Masyarakat dan Budaya, Vol 11, No. 15, 2020. URL: https://pmb.lipi.go.id/pandemi-covid-19-dan-nelayan-men yoal-dampak-pada-keberlanjutan-penghidupan/

[3] Komite Penanganan COVID-19 dan Pemulihan Ekonomi Nasional KPCPEN, "Peta Sebaran COVID-19", Satuan Tugas Penanganan COVID-19, covid19.go.id. covid19.go.id (accessed Jan. 13 ${ }^{\text {th }} 2021$ ).

[4] Munsir, I, "Kasus Aktiv COVID-19 di Makassar Tembus 4.400, dalam Sepekan Tambah 2.000", Detik Mews, news.detik.com (accessed Jan. 13 ${ }^{\text {th }}$ 2021).

[5] Naing, N., and Ikhsan, "Pemetaan Karakteristik Permukiman Kumuh Pesisir untuk Pengelolaan Bencana di Kota Makassar", Jurnal Arsitektur Kota dan Permukiman LOSARI, Vol. 1, No. 2, pp. 5-13, 2016. DOI: https://doi.org/10.33096

[6] Juhadi, Muis, A., Sriyanto, "Kearifan Lokal" in Kearifan Lokal dalam Mitigasi Bencana", Penerbit Fastindo, 2018, pp. 25-42.
[7] Hos, J. Sarpin, and Roslan, R, "Mitigasi Bencana Berbasis Kearifan Lokal pada Masyarakat Berpindah di Kecamatan Asera Kabupaten Konawe Utara", TALENTA Conference Series: Local Wisdom, Social, and Arts, Vol. 3, Issue 3, pp. 54-59. DOI: 10.32734/lwsa.v2il.602

[8] Tejakusuma, I.G, "Pengkajian Kerentanan Fisik untuk Pengembangan Pesisir Wilayah Kota Makassar", Jurnal Sains dan Teknologi Indonesia, Vol.13, No. 2, pp. 82-87, 2011. DOI: $10.29122 /$ jsti.v13i2.882

[9] Hidayat, A, "Analisis Pengembangan Kawasan Pesisir Berbasis Mitigasi Sea Level Rise (Kenaikan Muka Air Laut) Studi Kasus Kawasan Kota Lama Makassar", Jurnal Lingkungan Binaan Indonesia, Vol. 1, No. 1, pp. E_7-E_12, 2012. URL: https://jlbi.iplbi.or.id/wp-content/uploads/201 2/07/

[10] Yudono, A., Akil, A., and Arisandy, D.R., "Perspektif Sosio-Kultural: Sebuah Kearifan Lokal dalam Perencanaan dan Perancangan Kota Makassar", Jurnal Penelitian Enjiniring (JPE), Fakultas Teknik Universitas Hasanuddin, Vol.2, No.1, pp. 43-56, 2016. DOI: https://doi.org/10.25042/jpe.

[11] Syarif, E, "Kearifan Lokal dalam Pembentukan Konfigurasi Ruang Luar Permukiman Tepi Laut Mariso", Prosiding Seminar Archimariture IPLBI 3, Des., 2018, pp. A060-067. DOI: https://doi.org/10.32315/sem.3.a060

[12] Beddu, S., Akil, A., Osman, W. W., and Hamzah, B, "Eksplorasi Kearifan Budaya Lokal sebagai Landasan Perumusan Tatanan Perumahan dan Permukiman Masyarakat Makassar". Prosiding Temu Iliah IPLBI, Nov., 2014, pp. E_7-E_12. URL: https://temuilmiah.iplbi.or.id/e ksplorasi-kearifan-budaya-lokal-sebagai-landasan-perumus an-tatanan-perumahan-dan-permukiman-masyarakat-maka ssar/

[13] Direktorat Jendral Perlindungan dan Jaminan Sosial. "Kriteria Teknis Karantina dan Isolasi di Fasilitas Umum Berbasis Masyarakat", in Panduan Penyiapan Fasilitas Shelter untuk Karantina dan Isolasi terkait COVID-19 Berbasis Komunitas, Kemensos RI, 2020., pp. 11-19.

[14] Purnama, S.G., and Susanna, D, "Hygiene and Sanitation Challenge for COVID-19 Prevention in Indonesia", Kesmas: Jurnal Kesehatan Masarakat Nasional (National Public Health Journal), Special Issue 1, pp 6-13, 2020. DOI: 10.21109/kesmas.v15i2.3932

[15] Arifuddin, and Osman, W. W. "Bugis Local Wisdom in the Housing and Settlement Form: An Architectural Anthropology Study." Lowland Technology International, Vol. 9, No. 1, 2017, pp. 77-86.

[16] Moughtin, C. "Urban Design: Street and Square”. Lincare House, Jordan, Hill, Oxford, London, 1992.

[17] Peraturan Pemerintah Republik Indonesia Nomor 16 Tahun 2021 tentang Peraturan Pelaksanaan Undang-Undang Nomor 28 Tahun 2002 tentang Bangunan Gedung 